\title{
A single intramuscular injection of Gonadorelin [6-D-Phe] induces ovulation in the mare
}

\author{
Jan Hendrik Osmers ${ }^{b}$, Gunilla Martinsson ${ }^{b}$, Jutta Klewitz ${ }^{a}$, Corinna Linke ${ }^{a}$, Wolfgang Zaremba and Harald Sieme ${ }^{a}$
}

Clinic for Horses - Unit for Reproductive Medicine, University of Veterinary Medicine, Hannover, Germany; ; National Stud Lower Saxony, Celle, Germany and Clinic for Obsterics, Gynecology and Andrology of Small and Large Animals, Justus-Liebig-University, Giessen, Germanyc

\begin{abstract}
Summary
Artificial use of hormones in stud farm practice has become a widely used tool to enhance the success of equine breeding programs. Human chorionic gonadotropin (hCG) and GnRH implants are the most commonly used ovulation inducing agents. Despite their proven effectiveness, several disadvantages have been reported. Since there is no published data on the effect of the GnRH analogue Gonadorelin [6-D-Phe] (Gonavet Veyx ${ }^{\circledR}$ ) on ovulation in horses, it was the aim of this study to evaluate whether a single intramuscular injection is able to induce ovulation within 48 hours. A total of 82 mares received a treatment with $100 \mu \mathrm{g}$ of Gonadorelin [6-D-Phe] as soon as estrus and a follicle-diameter $>35 \mathrm{~mm}$ were detected. Manual rectal palpation and ultrasound examination were performed at 12-hour-intervals after the treatment. Eighty five percent of mares ovulated within 48 hours. Of the 18 untreated control mares, 38\% ovulated within 48 hours. The mean duration until ovulation in the Gonadorelin [6-D-Phe] and control group was $41 \pm 10.17$ and $57 \pm 15.15$ hours, respectively $(p<0.05)$. The efficacy of Gonadorelin [6-D-Phe] in inducing ovulation within 48 hours post application increased from early breeding season in February - March (75.9\%) to mid and late season in April - July (89.9\%). An influence of mare's age and/or reproductive status on the response to Gonadorelin [6-D-Phe] - treatment could not be observed. Gonadorelin [6-D-Phe] could be considered as a reliable and easy-to-use alternative to induce ovulation in the mare.
\end{abstract}

Keywords: mare, ovulation, GnRH, reproduction

\section{Einmalige Injektion von Gonadorelin [6-D-Phe] als neue Möglichkeit zur Ovulationsinduktion bei der Stute}

Der Einsatz von Hormonen zur Ovulationsinduktion bei der Zuchtstute findet in der Gestütsmedizin weitverbreitete Anwendung zur Verbesserung des Reproduktionserfolges. Humanes Chorion Gonadotropin (hCG) und GnRH-Implantate werden zur Ovulationsinduktion bei der Stute eingesetzt; abgesehen von deren erwiesenen Effektivität wird von unerwünschten Nebenwirkungen berichtet. Über das GnRH Analogon Gonadorelin [6-D-Phe] (Gonavet Veyx ${ }^{\circledR}$ ) liegen keine Berichte zum Einsatz bei der Stute mit dem Ziel der Ovulationsinduktion innerhalb $48 \mathrm{~h}$ post applikationem vor. Insgesamt 82 östrischen Stuten wurde bei Erreichen eines Durchmessers eines dominierenden Follikels von $>35 \mathrm{~mm} 100 \mu \mathrm{g}$ Gonadorelin [6-D-Phe] i.m. appliziert. Transrektale ultrasonographische Untersuchungen fanden im $12 \mathrm{~h}$ Intervall bis zur Feststellung der Ovulation statt. Innerhalb 48h post applikationem wurde bei 85\% der Stuten eine Ovulation festgestellt; in der unbehandelten Kontrollgruppe $(n=18)$ war dies bei 38\% der Stuten feststellbar. Der Mittelwert von Versuchsbeginn bis zur Feststellung der Ovulation betrug $41 \pm 10.17$ Stunden in der Gonadorelin [6-D-Phe]-Gruppe und 57 \pm 15.15 Stunden in der Kontrollgrupppe ( $<<0.05)$. Die Wirkungseffektivität von Gonadorelin [6-D-Phe] eine Ovulation innerhalb 48 Stunden post appl. zu induzieren verbesserte sich von der Phase der frühen Zuchtsaison (Februar - März, 75.9 \%) zur mittleren und späten Phase der Saison (April - Juli, 89.9 \%). Ein Einfluss des Alters der Stuten oder des Reproduktionsstatus war nicht feststellbar. Gonadorelin [6-D-Phe] kann als geeignete Alternative zur medikamentellen Ovulationsinduktion bei der Stute eingesetzt werden.

Schlüsselwörter: Reproduktion, Stute, Ovulation, GnRH

\section{Introduction}

Controlling the time of ovulation can reduce the times a mare is bred in the given estrus cycle and therefore save costs for semen shipping and optimize management and labor efficiency in equine facilities. Furthermore, the increased use of frozen semen in the globalized horse breeding business requires more precise instruments in controlling ovulation in the mare. The artificial use of hormones has become common practice to achieve these aims. Human chorionic gonadotropin ( $h \mathrm{CG}$ ) and $\mathrm{GnRH}$ analogues such as deslorelin are the most common ovulation-inducing agents nowadays. Despite their proven effectiveness, several negative effects on the efficacy have been reported for these drugs. McCue et al. (2004) describes a decrease in ovulation efficacy after several administrations of hCG in the same breeding season. The formation of hCG-antibodies as reported by Duchamp et al. in 1987 may enhance the time of ovulation after injection or prevent the ovulation at all. Another study (Siddiqui et al.
2009) considers hCG-antibodies capable of neutralizing the injected hCG within 30 hours. The use of the GnRH analogue deslorelin (Ovuplant ${ }^{\circledR}$ ) should cause prolonged intervals between the induced ovulation and the subsequent ovulation if the mare is not getting pregnant and the implant is not removed after the induced ovulation (McCue et al. 2002).

We were looking for a new easy to apply drug without adverse effects on ovulation induction and the same efficacy as hCG and deslorelin. At present, it seems that no one has tested the effect of Gonadorelin [6-D-Phe] to control the time of ovulation in horses. The aim of this study was to evaluate if a single intramuscular injection of the $\mathrm{GnRH}$ analogue Gonadorelin is able to induce ovulation within 48 hours. Gonadorelin [6-D-Phe] (Gonavet Veyx ${ }^{\circledR}$ ) is a decapeptide with an amino acid modification at position 6 that stabilizes the molecule against transforming enzymes, increases the plasma protein binding and enhances the binding capacity to the GnRH-receptor. 


\section{Material and methods}

Animals and experimental design

A total of 100 healthy, cyclic warmblood Hanoverian mares situated at the Lower Saxony State stud Celle, Germany were used in this study. All mares were stabled individually, had free access to water and were fed hay and oats twice daily. The investigations were carried out during the 2009 and 2010 breeding season between February and July of each year. The mares were assigned to two different groups after detection of estrus and determining a follicle $>35 \mathrm{~mm}$. The mares of group 1 ( $n=82$ ) received a single intramuscular injection of $100 \mu \mathrm{g}$ Gonadorelin [6-D-Phe] (Gonavet Veyx ${ }^{\circledR}$ ): mares of group 2 ( $n=18$ ) served as control mares and did not receive any treatment. In experiment 1, manual rectal palpation and ultrasound examination of the uterus and ovaries were performed at 12-hour intervals after treatment to determine ovulation.

In experiment 2, 27 Gonadorelin [6-D-Phe] treated mares were examined at $0,12,24$, and 30 hours post application, and then every 2 hours until ovulation, to determine the exact time of ovulation. In order to investigate the effect of follicular size on ovulation, mares with a follicular size between 35 and $40 \mathrm{~mm}$ were assigned to group $A(n=13)$ and mares with a follicular size greater than $40 \mathrm{~mm}$ to group $B(n=14)$.

Evaluation of pregnancy rates was based on pregnancy tests carried out between day 16 and 20 after insemination by the local veterinarian of each breeder. Mares with ovulation failure were excluded from this analysis.

\section{Ultrasonographic examination}

Sonographic measurements were carried out using a Logiq P 5 ultrasound device (GE Healthcare, Solingen, Germany), equipped with a linear probe (4 to $10 \mathrm{MHz}$, I 739, GE Healthcare, Solingen, Germany).

Statistical analysis

Statistical analyses were performed using the statistical analysis system 'Statview' (SAS Institute Inc., Cary, NC, USA). Intervals between Gonadorelin administration and ovulation were compared using one-way analysis of variance (or Wilcoxon's test for nonparametric data). Differences in fertility between groups were analysed using Chi-squared tests. In all cases, values are given as means \pm SD. Differences were considered significant at $\mathrm{P}<0.05$.

\section{Results}

A total of 82 mares received the Gonadorelin [6-D-Phe] treatment. Eighty five percent of mares ovulated within 48 hours after treatment and the mean time until ovulation was 41 hours. The ovulation of three mares was detected at 60 hours and two at 72 hours. Seven mares (8.5\%) failed to ovulate, three of them developed luteinisized anovulatory follicles and four ovulated after a second treatment with hCG (Ovogest ${ }^{\circledR}$ 1500 IE Intervet, Germany) at a later stage. Five of these seven non-responding mares were treated in the early transition period (February and March) (Tab. 1). Only $38 \%$ of the control mares ovulated within 48 hours and the mean duration until ovulation after assignment to the control group was 57 hours.

As shown in Table 1 Gonadorelin [6-D-Phe] was more effective for inducing ovulation later in the season, with 92 and $100 \%$ ovulating mares in June and July and only 87 and 64 $\%$ in February and March, respectively.

Table 2 shows that there is no significant effect of age and reproductive status on the time of ovulation, but more of the older mares failed to ovulate after treatment.

Under field conditions, the breeder chooses the stallion. Because of this a large number of stallions with differing fertility, either with fresh or frozen semen were used in this study. However there is no significant difference in pregnancy rates as shown in Table 3.

For mares not getting pregnant in the treatment cycle, the mean duration until the next ovulation was 21 days in the Gonadorelin [6-D-Phe] group and 20.5 days in the control group respectively.

In experiment 2 we attempted to determine the exact hour of ovulation. Twenty-seven mares were scanned at 2-hour intervals beginning 30 hours post treatment. The mean duration until ovulation in this experiment was 38 hours for group $A$ and 40 hours for group $B$. One group A mare and two group $B$ mares failed to ovulate in this experiment. Figure 2 shows that there is no correlation between the follicular size at the time of treatment and the subsequent ovulation time.

Table 1 Mean duration (hours) until ovulation after treatment of estrous mares with 100 $\mu \mathrm{g}$ Gonadorelin [6-D-Phe]/control group, assigned to the respective month of the breeding season.

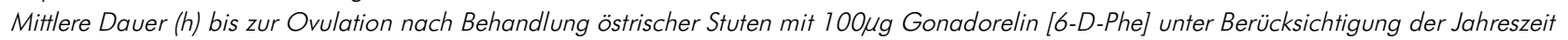

\begin{tabular}{|c|c|c|c|c|c|c|c|c|}
\hline \multirow[b]{2}{*}{ Month } & \multicolumn{4}{|c|}{ Gonadorelin } & \multicolumn{4}{|c|}{ Control } \\
\hline & average / h & $\mathrm{n}$ & $\%$ ov. within $48 \mathrm{~h}$ & ov. failure & average / $\mathrm{h}$ & $\mathrm{n}$ & $\%$ ov. within $48 \mathrm{~h}$ & ov. failure \\
\hline Feb & 36 & 8 & 87.5 & 1 & 0 & 0 & & 0 \\
\hline Mar & 44 & 14 & $64.3^{a}$ & 4 & 54 & 2 & 50.0 & 0 \\
\hline Apr & 46 & 15 & 80 & 0 & 48 & 2 & 100.0 & 0 \\
\hline May & 41 & 16 & 87.5 & 1 & 64 & 3 & 33.3 & 0 \\
\hline Jun & 39 & 13 & 92.3 & 1 & 51 & 4 & 50.0 & 0 \\
\hline Jul & 43 & 16 & $100^{\mathrm{b}}$ & 0 & 62 & 7 & 14.3 & 0 \\
\hline Total & $41 \pm 10.17$ & 82 & 85 & 7 & $57 \pm 15.15$ & 18 & 38 & 0 \\
\hline
\end{tabular}




\begin{tabular}{|c|c|c|c|c|c|}
\hline \multirow[b]{2}{*}{ Age } & \multirow[b]{2}{*}{ No. Mares } & \multicolumn{4}{|c|}{ Percentage of mares ovulating } \\
\hline & & $\leq 24 \mathrm{~h}$ & $25-48 \mathrm{~h}$ & $>48 \mathrm{~h}$ & ov. failure \\
\hline$<10$ years & 46 & 21.7 & 67.4 & 6.5 & 4.4 \\
\hline$>10$ years & 36 & 11.1 & 69.4 & 5.6 & 13.9 \\
\hline barren & 42 & 21.4 & 61.9 & 9.5 & 7.2 \\
\hline foal & 28 & 10.7 & 78.6 & 0 & 10.7 \\
\hline maiden & 12 & 16.7 & 66.7 & 8.3 & 8.3 \\
\hline
\end{tabular}

Table 3 Effect of treatment with $100 \mu \mathrm{g}$ Gonadorelin [6-D-Phe] on pregnancy rates in comparison to spontaneous ovulating mares (control). Pregnancy tests were performed between days 16 and 20 after inseminations with fresh or frozen/thawed stallion semen.

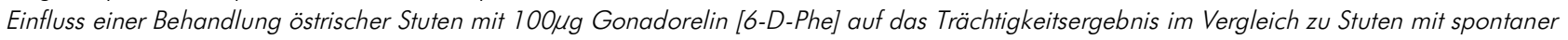
Ovulation (Kontrollgruppe). Trächtigkeitsuntersuchungen wurden 16-20 Tage nach Besamung der Stuten mit Frisch-oder Gefriersperma durchgeführt.

\begin{tabular}{lcccc}
\hline & \multicolumn{2}{c}{ Gonadorelin [6-D-Phe] } & \multicolumn{2}{c}{ Control } \\
\cline { 2 - 5 } Semen & no. cycles & pregnancy rate (\%) & no. cycles & pregnancy rate (\%) \\
\hline fresh Semen & 41 & 58.5 & 18 & 61.1 \\
frozen Semen & 34 & 76.5 & 0 & 0 \\
\hline Total & 75 & 67.5 & 18 & 61.1 \\
\hline
\end{tabular}

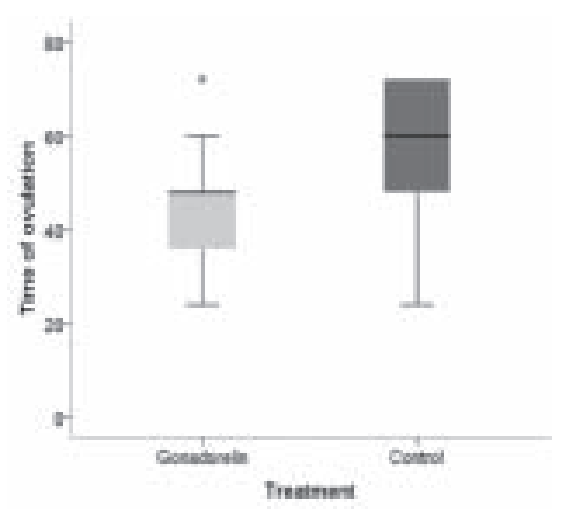

Fig. 1 [Experiment 1] Time until ovulation (hours) after i.m. injection of $100 \mu \mathrm{g}$ of Gonadorelin [6-D-Phe] in estrous mares. Gonadorelin [6-D-Phe] $(n=75)$, control $(n=18)$

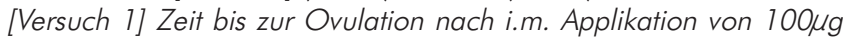
Gonadorelin [6-D-Phe] bei östrischen Stuten. Gonadorelin [6-D-Phe] $(n=75)$, Kontrollgruppe $(n=18)$

\section{Discussion}

Our study demonstrated that a single injection of $2 \mathrm{ml}$ Gonavet $V_{e y x}{ }^{\circledR}$ is consistently able to induce ovulation in mares. Eighty-five percent of mares ovulated within 48 hours, this rate is similar to the ovulation rates described for hCG (McCue et al. 2004) and deslorelin (Meinert et al. 1993). Gonadorelin [6-D-Phe] works as a GnRH agonist similar to deslorelin. Several authors mentioned that leaving the deslorelin implant in place after ovulation prolongs the interval between the induced ovulation and the subsequent ovulation when the mare does not become pregnant. McCue et al. (2002) described normal interovulatory intervals after removing the implant. All non-pregnant mares in this study had normal interovulatory intervals between 20 and 22 days. We can therefore assume that a single injection of $100 \mu \mathrm{g}$ Gonadorelin [6-D-Phe] does not have a negative effect on the interovulatory interval and that there is no down-regulation of

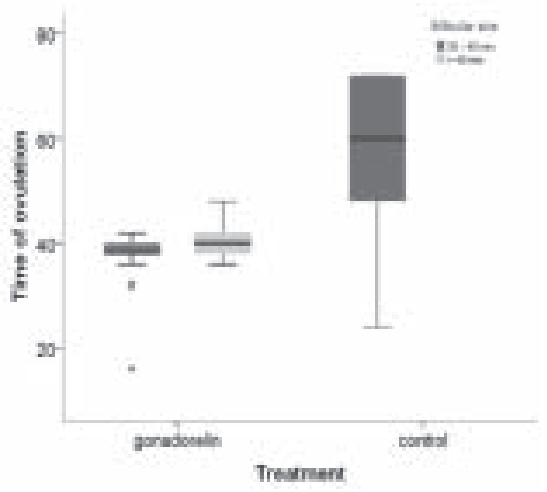

Fig. 2 [Experiment 2] Effect of follicular size at the time of i.m. injection of $100 \mu \mathrm{g}$ Gonadorelin[6-D-Phe] on the time until ovulation post application in estrous mares. Follicular size $35-40 \mathrm{~mm}$ $(n=13),>40 \mathrm{~mm}(\mathrm{n}=14)$, control $(\mathrm{n}=18)$

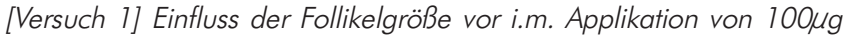
Gonadorelin [6-D-Phe] auf den Ovulationstermin bei östrischen Stuten. Follikelgröße 35-40mm ( $n=13),<40 \mathrm{~mm}$ Kontrollgruppe ( $n=18)$

the pituitary gonadotropin secretion as described for the deslorelin implant.

Because our study was a field study, the effect of more than one treatment per mare in subsequent cycles could not be analysed adequately. In four mares, we injected Gonadorelin [6-D-Phe] in two consecutive cycles. No negative effect on the ovulation time could be observed. Ovulation occurred twice after 36 and twice after 48 hours. Certainly further work on the reproducibility of this issue has to be done. But we think that there will not be a negative effect of several treatments in one breeding season as described for hCG by McCue et al. (2004), since there is no description of an antigenic effect of $\mathrm{GnRH}$ agonists.

As shown in Table 1, there is an effect of the season on the number of mares ovulating within 48 hours and the mares with ovulation failure. In February and March, the ovulation 
rate was lower than in late season. This phenomenon might result from seasonal changes in pituitary secretion and follicular disabilities to respond to the circulating $\mathrm{LH}$. Hart et al. (1984) described a markedly lower concentration of LH in the pituitary in the transitional period compared with the late breeding season. The higher number of anovulatory mares in February and March might also be due to this. Similar results were mentioned by Farquhar (2000), who described an effect of age and season for deslorelin. Our study also showed that the ovulation failure was greater in older mares. McCue et al. (2004) specified a higher incidence of persistent anovulatory follicles in older mares. The reproductive status of the mares had no influence on the time of ovulation.

In experiment 2, we tried to determine the exact time of ovulation, to facilitate insemination in reproductive programs. The mean ovulation time in group $A$ and $B$ mares was 38 and 40 hours, respectively. As shown in Figure 2, it might be helpful to induce the ovulation already in early estrus, with a follicular size between 35 and $40 \mathrm{~mm}$, because ovulation time was more precise in group A. With the knowledge of these results, a more accurate insemination, even with small doses of frozen semen, will be possible. We can therefore consider Gonadorelin [6-D-Phe] as a reliable and easy-to-use alternative to induce ovulation in the mare.

\section{Acknowledgement}

This study was kindly supported by Veyx Pharma GmbH, Schwarzenborn, Germany

\section{References}

Duchamp G., Bour B., Combranous Y. und Palmer E. (1987) Alternative solutions to $h C G$ induction of ovulation in the mare. J. Reprod Fertil. Suppl. 35, 221-228

Farquhar V. J. (2000). Efficacy of the GnRH agonist deslorelin acetate for inducing ovulation in mares relative to age of mare and season. Equine Vet. Sci. 20, 722-725

Hart P. J., Squires E. L., Imel K. J. und Nett T. M. (1984) Seasonal variation in hypothalamic content of gonadotropin-releasing hormone $(\mathrm{GnRH})$, pituitary receptors for $\mathrm{GnRH}$, and pituitary content of luteinizing hormone and follicle-stimulating hormone in the mare. Biol. Reprod. 30, 1055-1062

McCue P. M., Farquhar V. J., Carnevale E. M. und Squires E. L. (2002) Removal of deslorelin (Ovuplant) implant $48 \mathrm{~h}$ after administration results in normal interovulatory intervals in mares. Theriogenology 58, 865-870

McCue P. M., Hudson J. J., Bruemmer J. E. und Squires E. L. (2004) Efficacy of hCG at inducing ovulation: a new look at an old issue. In: 50th Annual Convention of the American Association of Equine Practitionners. Am. Assoc. of Equine Pract., Lexington, KY

Meinert C., Silva J. F., Kroetz I., Klug E., Trigg T. E., Hoppen H.-O. und Jöchle W. (1993) Advancing the time of ovulation in the mare with a short-term implant releasing the GnRH analogue deslorelin. Equine Vet. J. 25, 65-68

Siddiqui M. A., Gastal E. L., Gastral M. O., Beg M. A. und Ginther O. J. (2009) Effect of HCG in the presence of HCG antibodies on the follicle, hormone concentrations, and oocyte in mares. Reprod. Domest. Anim. 44, 474-479

Jan Hendrik Osmers

Clinic for Horses

Unit for Reproductive Medicine

University of Veterinary Medicine Hannover

Bünteweg 15

30559 Hannover

Germany

jhosmers@ewetel.net 